\title{
A COMPARISON OF DIRECT AND EXTRACTION METHODS FOR THE DETERMINATION OF T-1824 (EVANS BLUE) IN PLASMA AND SERUM
}

\author{
BY \\ J. F. MURRAY* AND J. P. SHILlINGFORD $\dagger$ \\ From the Department of Medicine, Postgraduate Medical School, London
}

(RECEIVEd For PUblication JULy 10, 1957)

The dye T-1824 (Evans Blue) has gained wide acceptance for determining plasma volume. Recently there has been a renewed interest in dye circulation studies for the measurement of cardiac output, central volume, cardiac shunts, and valvular regurgitation. The method of estimation most commonly used is spectrophotometric analysis of the dye-tinged plasma (or serum) compared with standard dye solutions prepared from the subject's plasma using a plasma blank (Chinard, 1951). Haemolysis and lipaemia introduce serious errors in these determinations (Gregersen, 1938). To overcome these factors, several extraction methods have been described (e.g., Allen, 1951 ; Bedwell, Patterson, and Swale, 1955).

To our knowledge no studies have been made on the relative values in routine clinical investigation of extraction and direct measurement of the dye in plasma (or serum). The purpose of this paper is to compare an acetone-extraction method with direct estimation in plasma and serum and to discuss their relative merits in clinical use.

\section{Methods}

A preliminary sample of venous blood was drawn from an indwelling needle to provide blank and standard solutions ; further samples were taken eight and 12 minutes after each injection of $T-1824$. The patients received two to four dye injections 15 to 30 minutes apart. Samples were placed in two dry, freshly siliconed tubes, one containing a small amount of powdered heparin as anticoagulant. Care was taken not to introduce bubbles or to cause excessive agitation when mixing. The mean concentration of the eight-minute and 12-minute samples was used in comparing the three methods described below.

A. Extraction Method.-A modification of the cellulose-absorption, acetone-elution method of Allen (1951) was used. One millilitre of a $50 \%$ aqueous

\footnotetext{
* Research Fellow of the American College of Physicians, 19561957.

+ Member, external staff, Medical Research Council.
}

solution of "teepol" 530 $\ddagger$ was added as a detergent to $2 \mathrm{ml}$. plasma, and the mixture was allowed to stand 10 minutes in a water-bath at $50^{\circ}$ C. A $1 \mathrm{~cm}$. cellulose $\S$ column was prepared in a Gooch crucible; the plasma was passed through this by gravity, and the column was then rinsed with teepolsaline, $1: 200(\mathrm{v} / \mathrm{v})$ solution. After suction to remove the excess saline solution, the crucible was placed in a clean funnel over a $10-\mathrm{ml}$. volumetric flask and the dye eluted with $50 \%$ acetone-water heated to $50^{\circ} \mathrm{C}$. in the water-bath. To start with, the acetone solution was added slowly but the rate was increased after dye appeared in the volumetric flask. After bringing to volume the optical density was determined on a "unicam" spectrophotometer at a wavelength of $620 \lambda$ using an acetone-water blank. As many as 10 samples can be analysed simultaneously in one to two hours.

The optical densities (O.D.) of two sets of duplicate standards were determined with each group of samples: standard No. 1, a known concentration of dye in the patient's plasma (usually $10 \mathrm{mg}$./1.), extracted with the other samples, and standard No. 2, an equal amount of dye (same pipette) brought to volume with acetone-water.

(1) $\frac{\text { O.D. extracted standard (1) }}{\text { O.D. non-extracted standard (2) }} \times 100=\%$ extraction

The dye-plasma samples are corrected for the percentage loss during the extraction and expressed in mg./l.

(2) $\frac{\text { O.D. unknown }}{\text { O.D. standard No. } 2} \times \frac{100}{\% \text { extraction }}=\frac{\text { unknown (mg./1.) }}{\text { standard (mg./1.) }}$ or simply:

(3)

$$
\frac{\text { O.D. unknown }}{\text { O.D. standard No. } 1}=\frac{\text { unknown (mg./1.) }}{\text { standard (mg./1.) }}
$$

Ordinarily, only standard No. 1 (known concentration of dye in patient's plasma for extractions), and equation (3) are used.

B. Direct Determination of Dye in Plasma.-After centrifugation, the optical density of the plasma was measured with the patient's plasma as a blank and

$¥$ Courtesy of Shell Petroleum Company. $\S$ Shredded " kleenex" in $0.9 \mathrm{~N} \mathrm{NaCl}$. 
measured amounts of dye in the subject's plasma as standards. Cuvettes contained $0.7 \mathrm{ml}$.

C. Direct Determination of Dye in Serum.-The blood was allowed to clot and retract. If the clot adhered to the side of the tube it was gently freed with a thin glass rod. After centrifugation the specimens and standards were prepared and measured as in B.

\section{Results}

Before comparing the extraction method with the non-extraction techniques, it was necessary to determine the validity of the former. In addition to extracting 24 plasma samples with known amounts of $\mathrm{T}-1824$ during the routine dye analysis of the patients studied, 77 plasma solutions of known and varied dye concentrations were analysed and the percentage extractions calculated.

The mean extraction of the 101 known samples, concentrations ranging from 3.85 to $20.0 \mathrm{mg}$. $/ 1$., was $93.7 \%$ (standard deviation $2.6 \%$ ). There was only a slight variation in extraction over the range of dye concentrations encountered in our studies that was not correlated with concentration (Table I). The percentage extraction varied from day to

TABLE I

PERCENTAGE EXTRACTION* FROM 5 TO 20 MG. L. DETERMINED ON FOUR SEPARATE DAYS

\begin{tabular}{c|c|c|c|c|c}
\hline Date & $\begin{array}{c}\text { O.D. } \\
\text { Blank }\end{array}$ & $\begin{array}{c}\text { Percentage } \\
\text { Extraction } \\
\text { 5 mg./1. }\end{array}$ & $\begin{array}{c}\text { Percentage } \\
\text { Extraction } \\
\text { 10 mg./1. }\end{array}$ & $\begin{array}{c}\text { Percentage } \\
\text { Extraction } \\
\text { 20 mg. I. }\end{array}$ & $\begin{array}{c}\text { Percentage } \\
\text { Variation }\end{array}$ \\
\hline 1 & 0 & 94.7 & 94.4 & 93.8 & 0.9 \\
2 & 0 & 90.5 & 92.2 & 90.9 & 1.7 \\
3 & 0 & 95.1 & 94.0 & 93.1 & 2.0 \\
4 & 0 & 95.9 & 93.9 & 95.1 & 2.0 \\
\hline
\end{tabular}

* All extractions and standards determined in duplicate.

day, mainly due to temperature changes, a higher extraction being found at higher temperatures; when allowance was made for this by analysis of variance, the standard deviation was reduced to $2.2 \%$. For this reason, correcting a group of samples for the daily extraction percentage gave an accuracy within the narrower range.

In preliminary experiments markedly haemolysed and lipaemic plasma blanks were analysed and an optical density of zero was invariably recorded as evidence of the complete removal of pigments and turbidity during the rinsing process ; also, after adding an equal amount of dye to haemolysed, lipaemic, and clear samples before extraction, the final optical density in all specimens agreed to within $2 \%$.

As the extraction was reliable over the dyeconcentration encountered in these clinical studies and was not influenced by haemolysis or lipaemia, it was used as a basis for comparing the direct
TABLE II

CONCENTRATION OF T-1824 OBTAINED BY DIRECT DETERMINATION IN PLASMA AND SERUM COMPARED WITH EXTRACTION VALUES CORRECTED FOR PERCENTAGE LOSS

\begin{tabular}{|c|c|c|c|c|c|c|}
\hline Subject & $\begin{array}{c}\text { Injec- } \\
\text { tion } \\
\text { No. }\end{array}$ & $\begin{array}{c}\text { Extrac- } \\
\text { tion } \\
(\mathrm{mg} .1 .)\end{array}$ & $\underset{\text { (mg./1.) }}{\text { Serum }}$ & $\begin{array}{l}\text { Percentage } \\
\text { Difference }\end{array}$ & $\begin{array}{l}\text { Plasma } \\
\text { (mg./1.) }\end{array}$ & $\begin{array}{l}\text { Percentage } \\
\text { Difference }\end{array}$ \\
\hline D.T. & 1 & $6 \cdot 1$ & - & 二 & $6 \cdot 0$ & $\overline{+}$ \\
\hline .F. & $\begin{array}{l}1 \\
2 \\
3\end{array}$ & $\begin{array}{r}5.53 \\
10.27 \\
15.32\end{array}$ & $\begin{array}{c}6.28 * \\
10.63 \\
15.53\end{array}$ & $\begin{array}{l}+13.6^{*} \\
+3.5 \\
+1.4\end{array}$ & $\begin{array}{l}5 \\
10\end{array}$ & $\begin{array}{r}0 \\
+\quad 3.2 \\
+\quad 5.5\end{array}$ \\
\hline w.S. & $\begin{array}{l}1 \\
2 \\
3\end{array}$ & $\begin{array}{r}15.32 \\
4.25 \\
8.71\end{array}$ & $\begin{array}{c}13.83 \\
9.47\end{array}$ & $\begin{array}{l}+1.4 \\
-12.9^{*} \\
+8.7\end{array}$ & $\begin{array}{r}4.59 \\
9 \cdot 16\end{array}$ & $\begin{array}{r}+5.3 \\
+\quad 8.0 \\
+\quad 5.2\end{array}$ \\
\hline I.S. & $\begin{array}{l}3 \\
1\end{array}$ & $\begin{array}{r}12.86 \\
4.77 \\
9.60\end{array}$ & $\begin{array}{r}13.53 \\
4.40 \\
9 \cdot 10\end{array}$ & $\begin{array}{r}+5.2 \\
-7.8 \\
-\quad 5.2\end{array}$ & $\begin{array}{r}13 . \\
3 . \\
8 .\end{array}$ & $\begin{array}{r}+6.4 \\
-17.2 \\
-7.4\end{array}$ \\
\hline & 3 & $14 \cdot 12$ & 13.57 & -3.9 & 13. & $\begin{array}{l}5.9 \\
-7.3 *\end{array}$ \\
\hline .L. & $\frac{1}{2}$ & $\begin{array}{r}4.54 \\
11.35\end{array}$ & $\begin{array}{r}4.27 \\
11.47\end{array}$ & $\begin{array}{r}-5.9 \\
+\quad 1.1\end{array}$ & $\begin{array}{r}4 . \\
12\end{array}$ & $\begin{array}{l}+7 \cdot 3^{*} \\
+6.3\end{array}$ \\
\hline .P. & 1 & $\begin{array}{r}4 \cdot 11 \\
8 \cdot 15\end{array}$ & $\begin{array}{r}3.73 \\
7.77\end{array}$ & $\begin{array}{r}9.2 \\
-4.7\end{array}$ & $\begin{array}{r}3.89 \\
7.57\end{array}$ & $\begin{array}{r}-5.4 \\
-7.1 \\
+\quad 2.4\end{array}$ \\
\hline B. & 3 & $\begin{array}{r}11.79 \\
4.57 \\
8.70\end{array}$ & $\begin{array}{c}11.06 \\
3.00 \dagger \\
7.17 \dagger\end{array}$ & $\begin{array}{r}-6.2 \\
-34.4+ \\
-17.6+\end{array}$ & $\begin{array}{r}12 . \\
4 . \\
8 .\end{array}$ & $\begin{array}{l}+2.4 \\
+9.0 \\
-6.8\end{array}$ \\
\hline & 3 & $13 \cdot 11$ & $11.53 \dagger$ & $-12.1 \dagger$ & 13. & $+3 \cdot 4$ \\
\hline W. & 1 & $\begin{array}{l}2 \cdot 82 \\
6 \cdot 28\end{array}$ & $\begin{array}{l}3 \cdot 16 \\
6 \cdot 71\end{array}$ & $\begin{array}{l}+12.1 \\
+6.8^{*}\end{array}$ & 2. & $\begin{array}{r}7 \cdot 1 \\
+\quad 3\end{array}$ \\
\hline & & & & +3.7 & & +0.1 \\
\hline . 0 . & 1 & $\begin{array}{r}5.65 \\
10.98\end{array}$ & $\begin{array}{r}5.77 \\
11.43\end{array}$ & $\begin{array}{l}+2 \cdot 1 \\
+4 \cdot 1\end{array}$ & $\begin{array}{r}5 . \\
11 .\end{array}$ & $\begin{array}{l}+2.1 \\
+0.6\end{array}$ \\
\hline & & 15.9 & 16.5 & + & & \\
\hline H. & 1 & 5.77 & $5 \cdot 78$ & +0.2 & 5. & $\begin{array}{r}-4.5 \\
-2.4\end{array}$ \\
\hline$. Y .+$ & 1 & $\begin{array}{r}4.41 \\
4.40\end{array}$ & 2.88 & -34.5 & $\begin{array}{l}1.67 \\
\end{array}$ & $-62 \cdot 0$ \\
\hline & & $8 \cdot 07$ & $6 \cdot 46$ & -20.0 & $4 \cdot 10$ & -49.2 \\
\hline $5 . ఛ$ & 1 & $\begin{array}{l}3 \cdot 1 \\
6 \cdot 2\end{array}$ & $\begin{array}{l}3.27 \\
6.94\end{array}$ & $\begin{array}{l}+ \\
+1\end{array}$ & $\begin{array}{l}4 \cdot 36 \\
8 \cdot 41\end{array}$ & $\begin{array}{l}+28.0 \\
+33.7\end{array}$ \\
\hline & & & & & & \\
\hline & & & & & & \\
\hline
\end{tabular}

* Haemolysed specimen. † Haemolysed blank. ‡ Lipaemic specimens (subject not fasting).

TABLE III

STATISTICAL COMPARISON OF DIRECT AND EXTRACTION VALUES AND VARIATION BETWEEN EIGHT- AND 12-MIN. SAMPLES

\begin{tabular}{|c|c|c|c|c|c|}
\hline \multirow{2}{*}{\multicolumn{2}{|c|}{ Method }} & \multicolumn{2}{|c|}{$\begin{array}{l}\text { Variation from } \\
\text { Extraction Value }\end{array}$} & \multicolumn{2}{|c|}{$\begin{array}{l}\text { Variation between } \\
\text { 8- and 12-min. Samples }\end{array}$} \\
\hline & & Mean & S.D. $(\%)$ & Mean & S.D. $(\%)$ \\
\hline Extraction .. & . & - & - & $1 \cdot 3$ & $1 \cdot 1$ \\
\hline $\begin{array}{l}\text { All samples } \\
\text { Clear samples }\end{array}$ & $\begin{array}{l}\ldots 1 \\
\ldots\end{array}$ & $\begin{array}{l}-1 \cdot 28 \\
-0.4\end{array}$ & $\begin{array}{r}17 \cdot 2 \\
6 \cdot 5\end{array}$ & $2 \cdot 8$ & $3 \cdot 3$ \\
\hline $\begin{array}{l}\text { Serum } \\
\text { All samples } \\
\text { Clear samples }\end{array}$ & $\begin{array}{l}\cdots \\
\ldots !\end{array}$ & $\begin{array}{r}-2.8 \\
+0.4\end{array}$ & $\begin{array}{r}12 \cdot 1 \\
5 \cdot 8\end{array}$ & $2 \cdot 7$ & $3 \cdot 1$ \\
\hline
\end{tabular}

methods (Tables II and III). The mean difference between the eight- and 12-minute extracted samples was $1.3 \%$ (standard deviation $1.1 \%$ ), further indication of the reliability of the method.

Direct Estimation in Plasma. - Excluding samples with haemolysis or lipaemia (patients F.Y. and P.S. had inadvertently eaten before the study). correlation (Table II, Fig. 1) is reasonably good, although the deviation of results and variation 


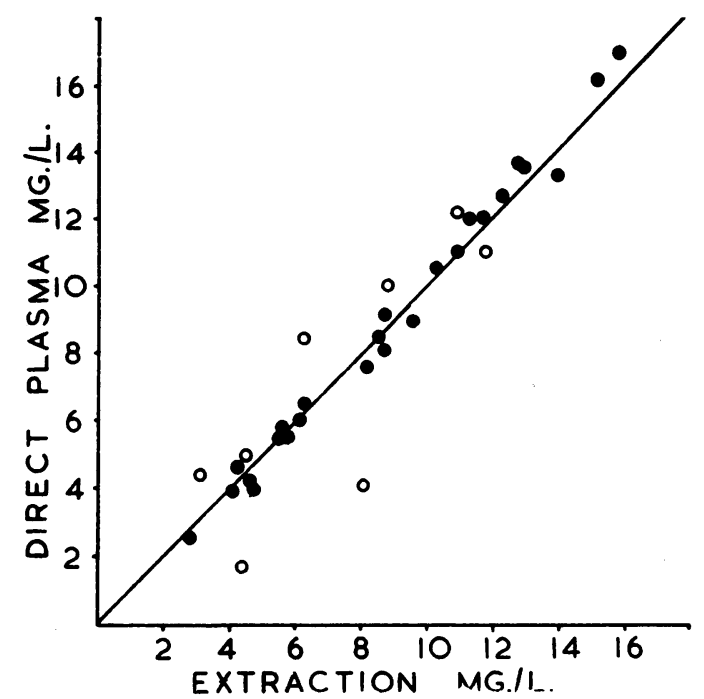

Fig. 1.-T-1824 concentration obtained from optical density of plasma compared with value by extraction method. The line of identity is shown. The solid circles are clear specimens, the open circles haemolysed or lipaemic samples.

between eight- and 12-minute samples is greater than with the other methods (Table III).

Direct Estimation in Serum.-There is slightly better agreement (Table II, Fig. 2) with extraction values than was found with plasma; although haemolysis was more commonly encountered in handling serum, the effect of haemolysis and lipaemia was less marked (Table III).

\section{Discussion}

Figs. 1 and 2 show that even under ideal conditions in which the patient is fasting, and the plasma is not lipaemic or haemolysed, the direct method of estimating $\mathrm{T}-1824$ concentration in plasma (or serum) has an error of approximately $6 \%$. The occasional occurrence of lipaemia or haemolysis (approximately 10\% of samples) will introduce considerably more error in the determination. The extraction technique, on the other hand, has an error of only $2.2 \%$ and is not influenced by the presence of-haemolysis or lipaemia.

The accuracy of blood volume studies using a 10-minute sample and of indicator dilution curves recorded with an oximeter depends largely upon the accuracy of the measurement of $T-1824$ concentration in a single specimen. Use of the direct method of analysis in these procedures may introduce an error of considerable magnitude in the final results.

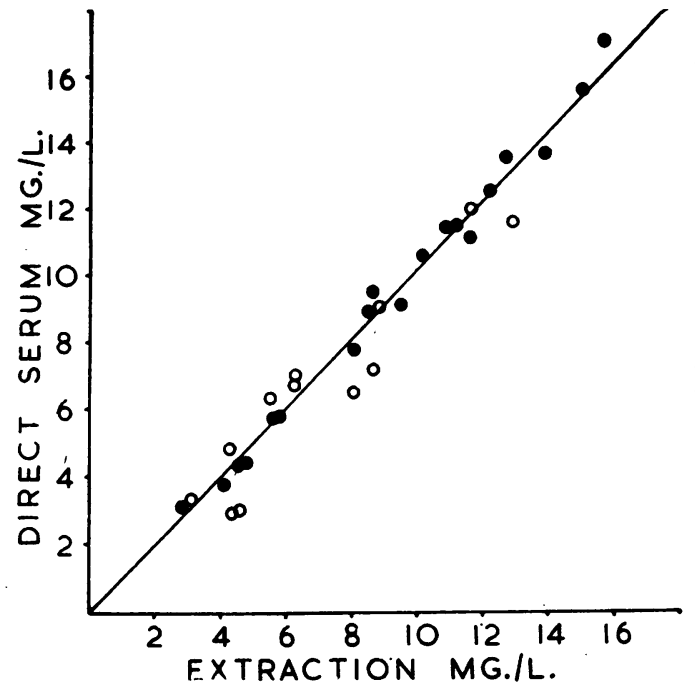

FIG. 2.-T-1824 concentration obtained from optical density of serum compared with value by extraction method. The line of identity is shown. The solid circles are clear specimens, the openç circles haemolysed or lipaemic samples.

The extraction yield of $93.7 \%$ in the present? study is not as high as the $97 \%$ reported by Allen (1951) and Bedwell et al. (1955) using similaro methods. The reason for the lower yield is prob-市 ably that we have worked at a lower temperature than have the other workers. The method has, however, given consistent results (known and $\frac{3}{5}$ duplicate solutions) in over 200 samples and has the added advantage of permitting simultaneous analysis of multiple samples.

\section{Summary}

A comparison was made of three methods for estimating the concentration of $\mathrm{T}-1824$ in dye-음 circulation studies, namely, $(a)$ an acetone- $\rightarrow$ extraction method, $(b)$ direct determination from optical density in plasma, and (c) direct determina-ñ tion from optical density in serum.

Direct estimation in the presence of lipaemia or 0 haemolysis may be accompanied by considerable $e_{\omega}^{N}$ error.

The accuracy and reliability of the extractione method are discussed. In this laboratory it proved ${ }_{\overparen{D}}^{\tau}$ to be the most satisfactory for $\mathrm{T}-1824$ analysis.

\section{REFERENCES}

Allen, T. H. (1951). Proc. Soc. exp. Biol. (N.Y.), 76, 145. Bedwell, G. A., Patterson, J., and Swale, J. (1955). J. clin. Path., 8, 61 Chinard, F. P. (1951). Meth. med. Res., 4, 38.

Gregersen, M. I. (1938). J. Lab. clin. Med., 23, 423. 